\title{
The anatomy of the fruit in relation to the propensity of citrus species to split
}

\author{
A. García-Luis*, A.M.M. Duarte1, M. Kanduser, \\ J.L. Guardiola \\ Departamento de Biología Vegetal, Universidad Politecnica de Valencia, \\ 46071 Valencia, Spain
}

\begin{abstract}
The anatomy of the fruit has been compared in three prone-to-split mandarin hybrids (Nova, Ellendale and Murcott), several cultivars of clementine mandarin (Fino, Clementina de Nules and Orogrande), and in Owari satsuma mandarin. The fruit of the hybrids is oblate to subglobose and usually presents an open stylar end disrupted by a navel formed by the - oral meristem, which is conserved near the apex of the fruit. In the non-prone-to-split clementines as well as in Owari satsuma, the ${ }^{-}$oral axis protrudes inside the style, and the ${ }^{-}$ower meristem is lost through abscission shortly after petal fall. The abaxial side of the carpels fuses with the - ower axis forming at the stylar end of the fruit a solid tissue which externally has a small scar at the place of style abscission. Most of the fruits in these cultivars have no navel. In addition, the fruit of clementine is slightly oblate or globose. The relevance of these anatomical characteristics as regards to splitting is supported by the differences between the split and non-split fruits in Nova, the split fruit being more oblate in shape and having a bigger navel than non-split fruit. However, the effect of applied growth regulators on fruit splitting could not be correlated with their effect on the anatomy of the fruit. Additional factors not contemplated in the study also in ${ }^{-}$uence fruit splitting.
\end{abstract}

Keywords: Citrus; Clementine; Fruit anatomy; Fruit splitting; Growth regulators; Hybrid mandarins; Satsuma 


\section{Introduction}

Preharvest fruit splitting is a physiological fruit disorder of citrus fruit which is considered to result from the pressure of the rapidly expanding juice vesicles on the thin, stretched peel (Erickson, 1968). Although different patterns for the development of this alteration have been described (del Rivero, 1968), it usually begins as small cracks at the stylar end of the fruit which further develops into larger longitudinal $® s s u r e s$ which progress towards the equatorial region. The affected fruit usually drops at an early stage of splitting.

This alteration may be found in a variable and normally small amount of fruits in every citrus cultivar. In some cases, however, the number of fruits affected is exceedingly high, a situation reported for several cultivars of navel oranges such as Washington (Erickson, 1968; Lima and Davies, 1984), Navelina (De Cicco et al., 1988; Ruiz and Primo-Millo, 1989), and Skaggs Bonanza (Monselise et al., 1986) in Valencia orange (Bar-Akiva, 1975), and particularly in several mandarin hybrids such as Murcott, Ellendale, Nova and Niva (Monselise et al., 1986; Ruiz and Primo-Millo, 1989; Goldschmidt et al., 1992;

García-Luis et al., 1994; Rabe and Van

Goren et al., 1992; Almela et al., 1994;

Rensburg, 1996; Barry and Bower, 1997). In these hybrids, the losses caused by this alteration may represent up to $50 \%$ of the potential yield, making it uneconomical to grow these cultivars in some climatic areas. In contrast, this alteration rarely affects mandarin cultivars of the clementine and satsuma groups.

The incidence of this alteration has been related to environmental and mineral nutrition parameters, but no single factor has been characterised as responsible for it, nor ef®cient corrective measures have been developed so far. Con ${ }^{-}$icting reports are found in the literature on the effectiveness of several cultural practices. The application of potassium and calcium has been reported to reduce splitting (Monselise et al., 1986; De Cicco et al., 1988; Ruiz and Primo-Millo, 1989; Almela et al., 1994), to have no consistent effect (García-Luis et al., 1994; Barry and Bower, 1997), or to increase it (Rabe and Van Rensburg, 1996). The same variability is found in the response to 2,4-D sprays, which have been reported to reduce (Monselise et al., 1986; Almela et al., 1994) or to have no consistent effect on splitting (Goren et al., 1992; Barry and Bower, 1997). A climate effect seems likely, as splitting is most prevalent in humid and warm climates (Alexander, 1983; Saunt, 1990), but the reason of this effect has not been ascertained. Splitting has been shown to decrease under reduced water supply (Goldschmidt et al., 1992; Goren et al., 1992), to be inversely related to water availability (De Cicco et al., 1988) or as being unrelated to rainfall (Rabe and Van Rensburg, 1996). On the other hand, treatments aiming to increase fruit set, either girdling or GAз sprays at full bloom, have been reported invariably to increase splitting both in absolute and in relative terms (Goren et al., 
1992; García-Luis et al., 1994; Rabe and Van Rensburg, 1996; Barry and Bower, 1997).

The con ${ }^{-}$icting reports quoted above indicate that fruit splitting is a complex phenomenon which may be determined by a combination of factors. However, as it is most frequent in some cultivars, they should share some characteristic(s) determinant for the incidence of this alteration. This aspect does not seem to have been explored in detail. Lima and Davies (1984) observed that split fruit of Washington navel orange had a bigger navel opening than non-split fruit. GarcíaLuis et al. (1994) reported that splitting in Nova is related to the presence of an open stylar end in the fruit and a navel. Rabe and Van Rensburg (1996) stated that the potential for fruit splitting in Ellendale tangor is determined during the early stages of fruit development, but the cause of it was not ascertained. In the present report, the anatomical characteristics of the ovaries and fruitlets of cultivars prone to splitting, and those of cultivars which usually do not split, have been compared. The relationship between the anatomy of the fruit and splitting was further explored in the hybrid Nova, comparing the characteristics of non-split and split fruits, and the effect of hormone treatments both on splitting and the anatomy of the fruit.

\section{Material and methods}

\subsection{Varietal differences in the anatomy of ovaries and fruitlets}

The anatomical observations were performed on the cultivars Fino, Orogrande and Clementino de Nules of clementine mandarin (Citrus clementina Hort. ex Tanaka), Owari satsuma (Citrus unshiu Marc.) and the hybrids Nova, Murcott and Ellendale. Nova is a hybrid of clementine mandarin and Orlando tangelo (Citrus paradisi Macf.ÂCitrus tangerina Hort. ex Tanaka) obtained by Gardner and Bellows (Hodgson, 1967). Murcott and Ellendale are hybrids of unknown parentage considered to be natural tangors (Hodgson, 1967). These three hybrids are very prone to cracking, particularly when grown in hot and humid areas. Fruit cracking occurs sporadically in clementines and satsuma.

Flower buds at different stages of development, open ${ }^{-}$owers and developing

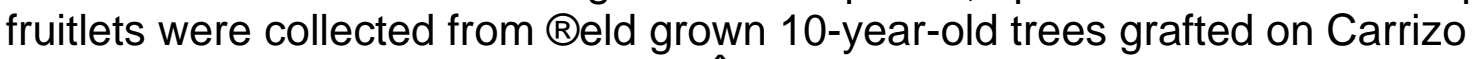
citrange (Citrus sinensis (L.) OsbeckÂPoncirus trifoliata (L.) Raf.). Either fresh or $® x e d$ material was sectioned at $15 \mathrm{~mm}$ with a freezing microtome, and the sections mounted on glass slides and stained either with periodic acid Schiff (Jensen, 1962) or with iodine green carmin (Johansen, 1940). For scanning electron microscopy the $\circledast x$ xed samples were dehydrated in a graded ethanol series, critical point dried with $\mathrm{CO}_{2}$, coated with gold \pm carbon and viewed in a Nikon electron microscope. 


\subsection{The anatomy of the fruit in relation to splitting}

This study was performed on fruit bearing adult (10-year-old) Nova trees grafted onto Carrizo citrange rootstock. Forty trees were sprayed at full bloom, on 16 April, either with a $20 \mathrm{mg}$ là1 solution of the isopropyl ester of 2,4dichlorophenoxyacetic acid (2,4-D) or $20 \mathrm{mg}$ là1 solution of gibberellic acid $\left(G_{3}\right)$. The applications were repeated on 15 May, at petal fall, on the same trees, which were sprayed twice with the same hormone solution. Forty unsprayed trees served as controls. The spray treatments were allocated in a randomised design with four 10-tree plots. Periodically, random fruitlet samples were taken to determine the effect of the applications on fruitlet growth and characteristics, and to compare the characteristics of split and non-split fruits. The split fruits were counted at weekly intervals and removed. At harvest, the total number of remaining fruits were counted, and from this value and the number of split fruits removed, the number of fruits set were calculated. Splitting is expressed either in absolute terms (number of split fruits per tree) or relative to fruit set (per cent of fruit splitting).

Morphological differences between the split and the non-split fruits before the occurrence of splitting were determined tagging 200 fruits from leafy in ${ }^{-}$orescences by mid-June, more than 2 months before the beginning of splitting. Periodically, the diameter and the height of these fruits were measured. At the end of fruit development, these fruits could be classed as split and non-split fruits, and in this way the morphology of these two fruit classes before the occurrence of splitting could be determined.

\section{Results}

\subsection{Varietal differences in the anatomy of ovaries and fruitlets}

The early stages of ovary formation were similar in all cultivars and are shown in Fig. 1 for Owari satsuma. A single whorl of about 10 carpel primordia were formed at a distance of $100 \mathrm{~mm}$ from the apex of the ${ }^{-}$oral axis in $2 \mathrm{~mm}$ wide - ower buds (Fig. 1A). These carpel primordia grew both marginally and apically, outgrowing the - oral axis and becoming horseshoe-shaped in transection. The growth of the margins toward the centre formed open furrows which shall become the loculi of the fruit (Fig. 1B). The apex of the carpels curved inwardly, and the abaxial side of each of the wings of the carpel fused with the adjacent carpel, this fusion progressing from the basis to the apex (Fig. 1C). This process formed a deep cup-like structure with a narrow opening at the apex and the ${ }^{-}$oral meristem at its bottom (Fig. 1D). About the time of ovary closure the tissues at the top of the ovary extended vertically to form a single compound style with as many stylar 

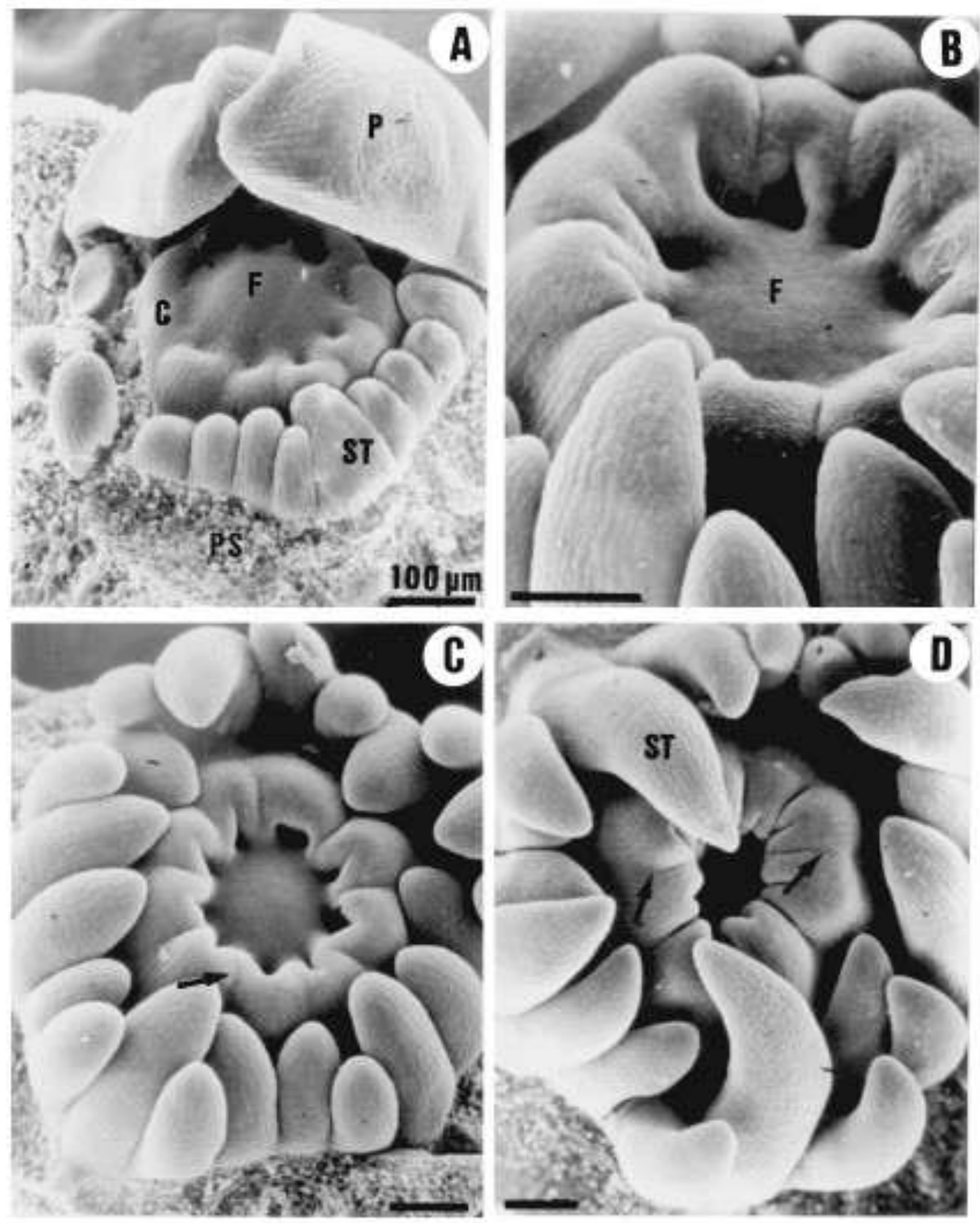

Fig. 1. Scanning electron micrographs of Owari satsuma mandarin - ower buds showing the early stages of pistil development. (A) Floral apex with the sepals and three petals removed showing a whorl of stamen primordia and the initiation of the carpels at the ${ }^{-}$anks of the ${ }^{-}$oral meristem. (B) Slightly older ${ }^{-}$ower bud in which the carpel primordia have overgrown the ${ }^{-}$oral meristem. (C) and (D): The further apical growth and the inwardly curling of the carpel primordia forms a narrow mouthed deep cup with the ${ }^{-}$oral meristem in its bottom. The side walls of some adjacent carpels have fused to form the septa (arrows). Scale bars: $100 \mathrm{~mm}$. C: carpel primordia; F: ' oral meristem; P: petal; PS: petal scar; S: sepal; ST: stamen.

canals as carpels, and the - oral meristem extended to form a column which merged and fused with the margins of the carpels to form the axis of the fruit. In the different cultivars this central column varied greatly in length and in the extent of the fusion with the carpels. 

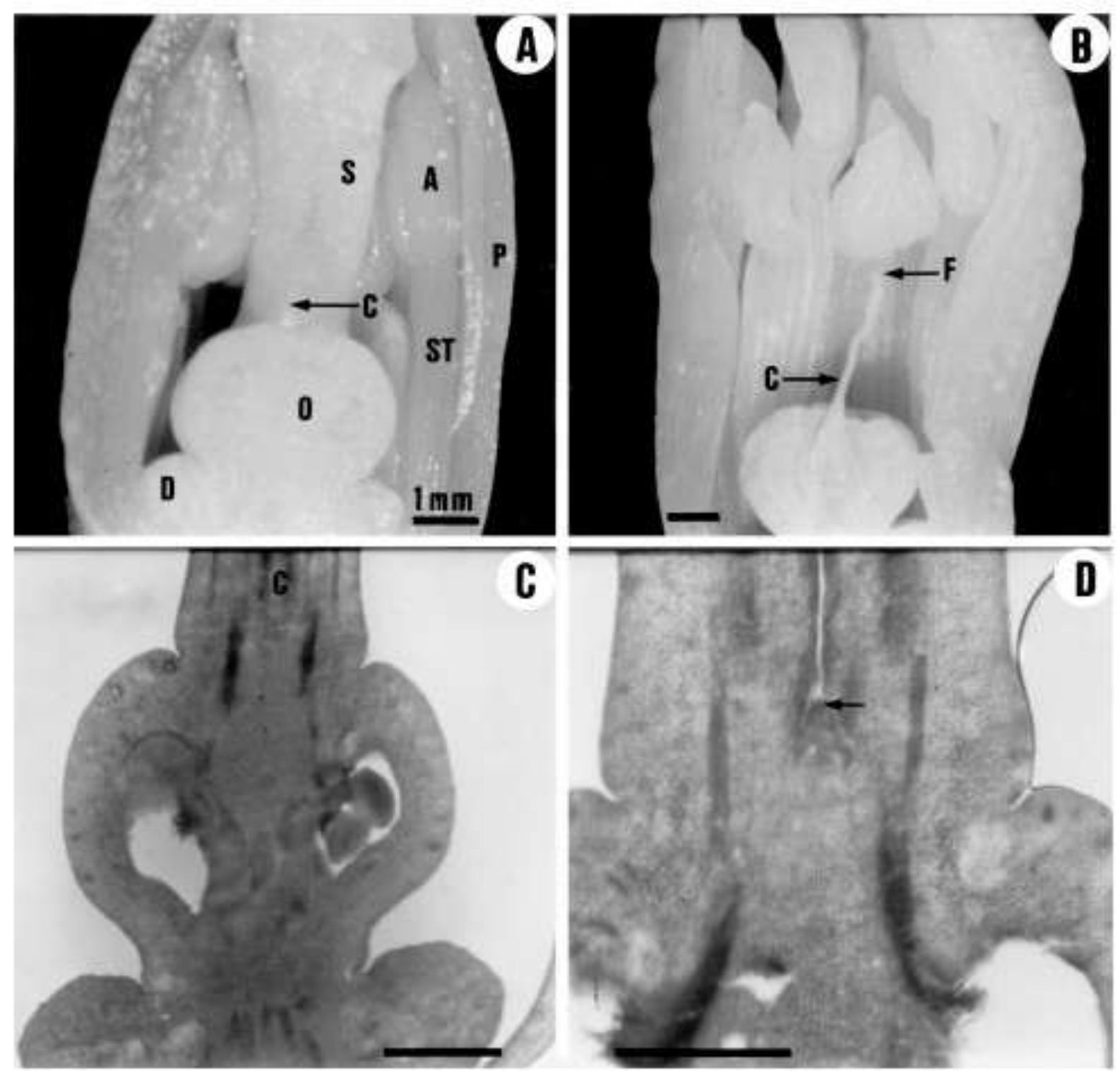

Fig. 2. (A) Bright-®eld micrograph of a longitudinally sectioned Clementina de Nules ${ }^{-}$ower bud showing the protrusion of the column (arrow) through the centre of the single compound style. (B) The - ower bud from A with the style surgically removed to show the column. (C) and (D) Longitudinal sections of Fino clementine - owers. In $(C)$ the column penetrates the style beyond the (Beld of the photograph; in (D) the - oral meristem (arrow) had ceased to grow some $0.5 \mathrm{~mm}$ above the ovary. Scale bars: $1 \mathrm{~mm}$. A: anther; C: column; D: disk; O: ovary; P: petal; S: style; ST: stamen.

In all the clementine cultivars studied, the column was longer than the ovary and penetrated the style in a variable length (Fig. 2). At the ovary level and in the junction with the style, the fusion of the column with the carpels was so complete that the boundaries of these organs could not be distinguished (Fig. 3A and B).

The base of the style showed more intense staining in the cells of the column with Schiff's reagent than the carpel-derived tissue, and there were some discontinuities in the fusion of these tissues (Fig. $3 \mathrm{C}$ and D). Further up along the style these organs were unfused, and both the column and the central cavity in the style were lined by an epidermis (Fig. 3E and F). Still further up along the style, the 

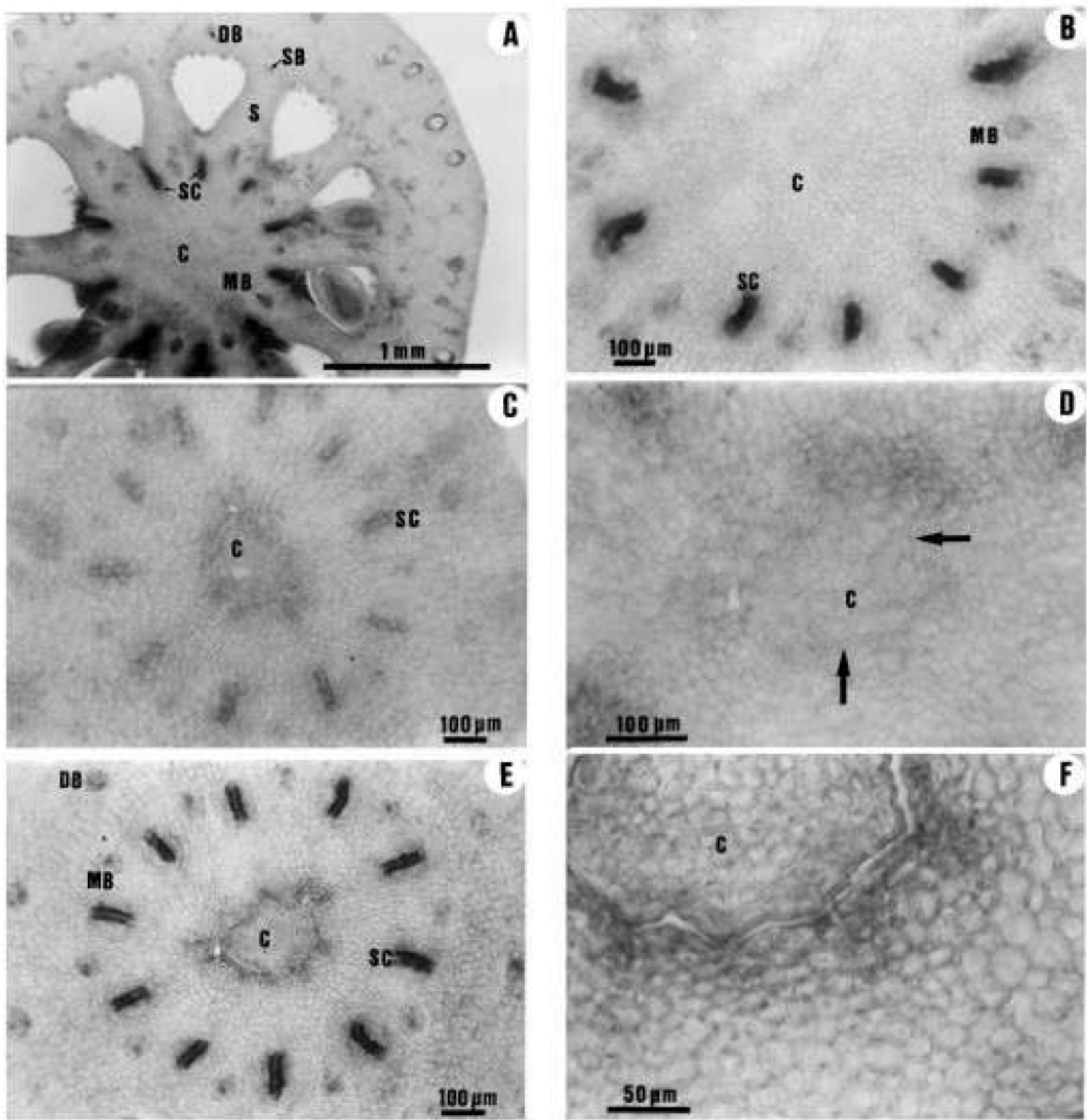

Fig. 3. Transverse sections through the ovary and the style of Fino clementine at anthesis showing the fusion of the carpels and the column. (A) Section through the apical (stylar) region of the ovary, where the stylar canals open into the loculi. The abaxial side of adjacent carpels have fused to form a compound septa whose margins are fused to the column. (B) An enlarged view of the central axis region in $(A)$, showing a parenchymal tissue in which the origin of the cells cannot be distinguished. (C) Section through the basal part of the style showing the more intense staining in the cells of the column than in the surrounding cells from the carpels. (D) An enlarged view of the central region in (C) showing discontinuities in the fusion of the column with the carpelar tissues (arrows). (E)

Section through the mid-section of the style. The column is not fused with the carpelar tissues. $(F)$ An enlarged view of the central region in (E) showing the presence of an epidermis both in the column and in the central hollow formed by the fused carpels. C: column; DB: dorsal vascular bundle; MB: marginal vascular bundle; SB: septal vascular bundle; S: septa; SC: stylar canal. 


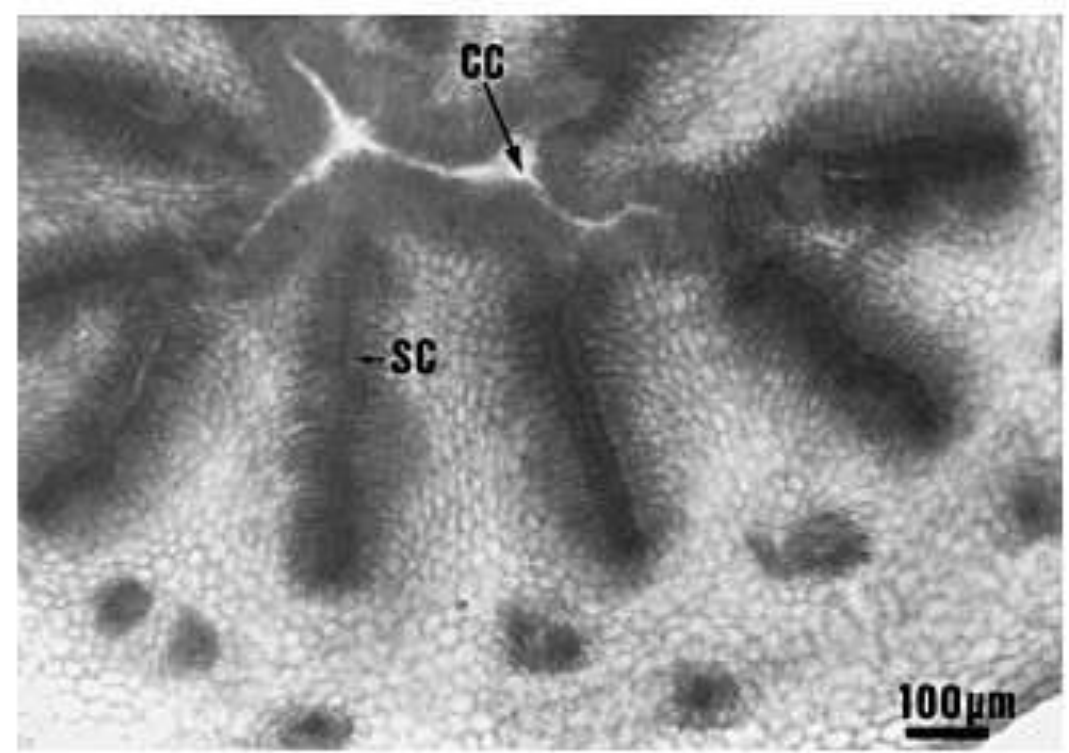

Fig. 4. Transverse section through the upper region of a Clementina de Nules style beyond the - oral meristem. There is a central cavity lined by an epidermis. CC: central cavity; SC: stylar canal.

column was not present, and the centre of the style had a narrow cavity lined with an epidermis (Fig. 4). In most fruits, the column extended beyond the abscission zone of the style, so that the - oral meristem was lost through abscission.

In the cultivars Clementina de Nules and Orogrande, the anatomical structure of the style at the abscission zone in most fruits was as shown in Fig. 3B and D, and the suberißcation of the abscission layer resulted in the formation of a scar that at fruit maturity was $1 \pm 2 \mathrm{~mm}$ wide (Fig. 5). In a signi®cant proportion of fruits of Fino clementine, the central column grew less than in the other clementine cultivars (Fig. 2D), and the structure of the style at the abscission zone was as shown in Fig. 3F. Shortly after style abscission, the upper part of the column dried out, and the fruits showed at maturity a nearly circular $2 \pm 3 \mathrm{~mm}$ wide opening at the apex and limited by an exocarp-like tissue (Table 1) formed by the inner epidermis of the style.

The structure of the satsuma ovaries was similar to that described above for Fino clementine (Fig. 6). In most cases, the column formed by the ${ }^{-}$oral meristem extended beyond the abscission zone of the style, and the meristem was lost when abscission of the style occurred (Fig. 6A). In some ovaries, the apex of the column did not reach the base of the style, and the ${ }^{-}$ower meristem was conserved after style abscission enclosed within the mesocarp at the stylar end of the fruit (Fig. 6B). In these fruits, the ${ }^{-}$oral meristem formed a limited amount of pericarp-like tissue, which could be seen at the apex of the mature fruit at the centre of the stylar scar.

In the - owers of the hybrids studied, the - oral meristem made very little grow and the resulting column was very short. The apex of the carpels curled downward to fuse with the apical part of the column, forming a cavity between 

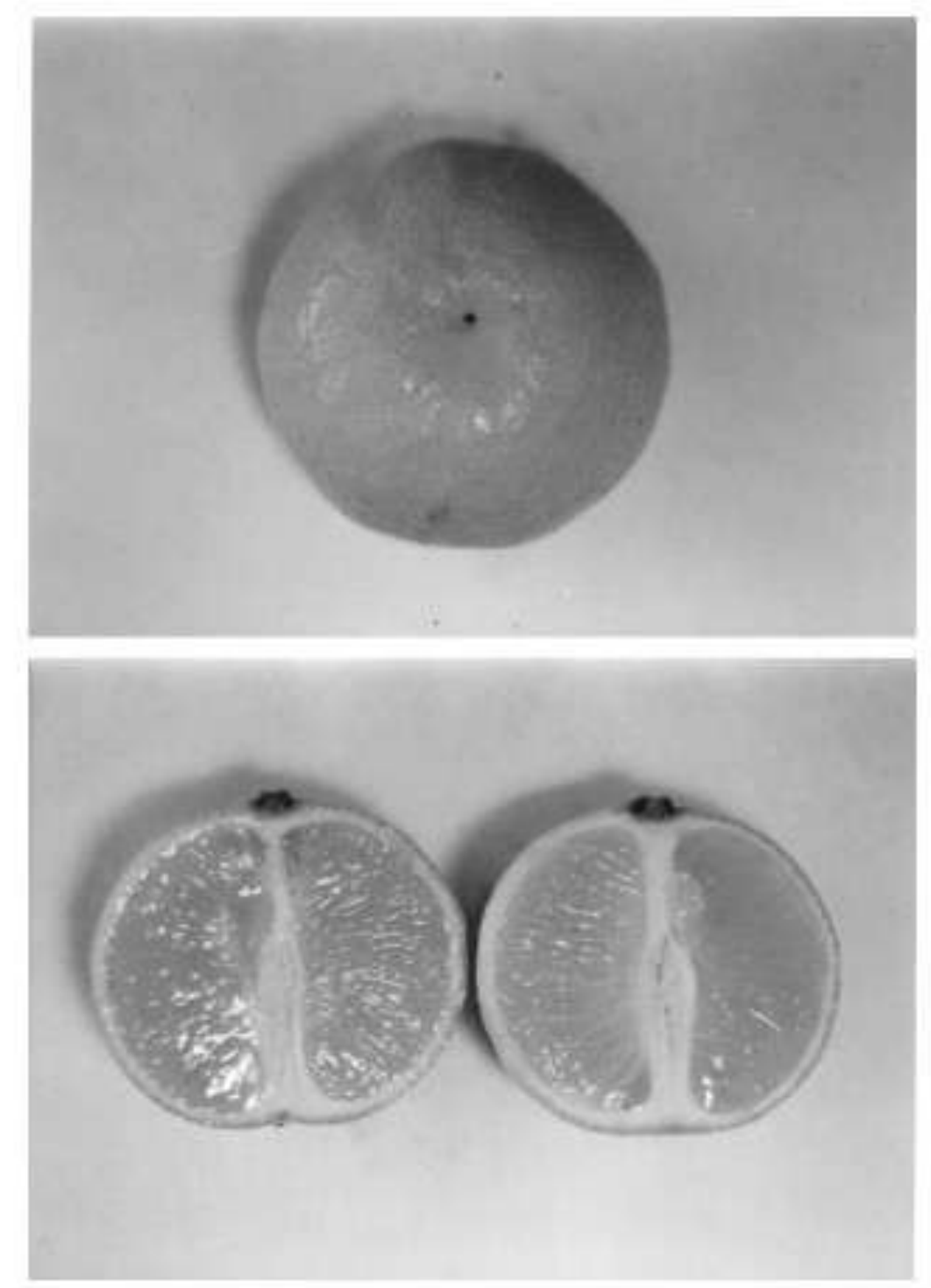

Fig. 5. Morphology of the stylar end of the fruit of Orogrande clementine at harvest. Typically it presents a small scar ( $1 \pm 2 \mathrm{~mm}$ wide) at the site of style abscission. The longitudinal section of the fruit shows that the peel is thicker at the stylar end, and also the uniform thickness of the ${ }^{-}$avedo.

Table 1

Morphology of the stylar end of the fruits at maturity

Percentage of fruits with the apex having

\begin{tabular}{lccc} 
& Stylar scar & Open end & Cracks \\
\hline Clementine & 67 & 33 & 0 \\
Fino & 100 & 0 & 0 \\
Orogrande & 100 & 0 & 0 \\
Clementina de Nules & 72 & 12 & 16 \\
Nova & 68 & 20 & 12 \\
Murcott & 31 & 69 & 0 \\
Ellendale & & &
\end{tabular}



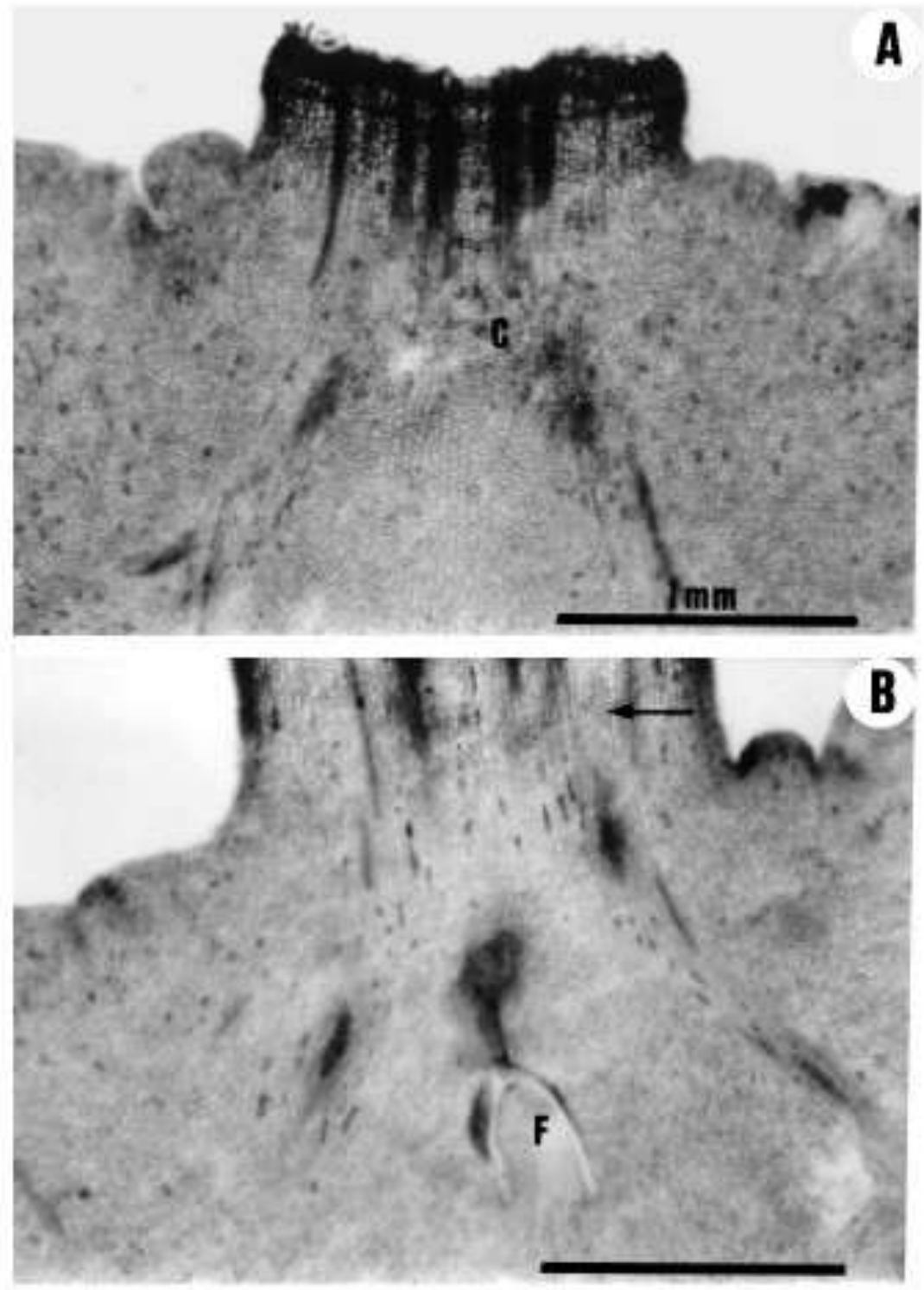

Fig. 6. Longitudinal section of pistils of satsuma mandarin. (A) Apical portion of a fruitlet shortly after style abscission with the column extending up to the suberised abscission layer of the style. (B) Apical portion of a fruitlet shortly before style abscission with the - oral meristem buried deep in the mesocarp below the forming abscission layer in the style (arrow). Scale bars: $1 \mathrm{~mm}$. F: ${ }^{-}$oral meristem.

the apex of the ovary and the base of the style in which the - oral meristem was held (Fig. 7). The style of these hybrids was hollow from its base, with a narrow central cavity lined by an epidermis which protects the unfused margins of the laterally fused carpellary outgrowths which form the single compound style (Figs. 7 and 8). The abscission of the style in these cultivars occurred above the position of the - oral meristem, which was conserved in most of the developing fruitlets (Fig. 7). The conserved ${ }^{-}$oral meristem made a signi®ißcant growth after style abscission forming an exocarp-like tissue at the stylar end of the fruit which was visible in most of the fruits (Fig. 9, Table 1). The growth of this tissue was related to fruit shape and stylar end splitting (Tables 2 and 3 ). 

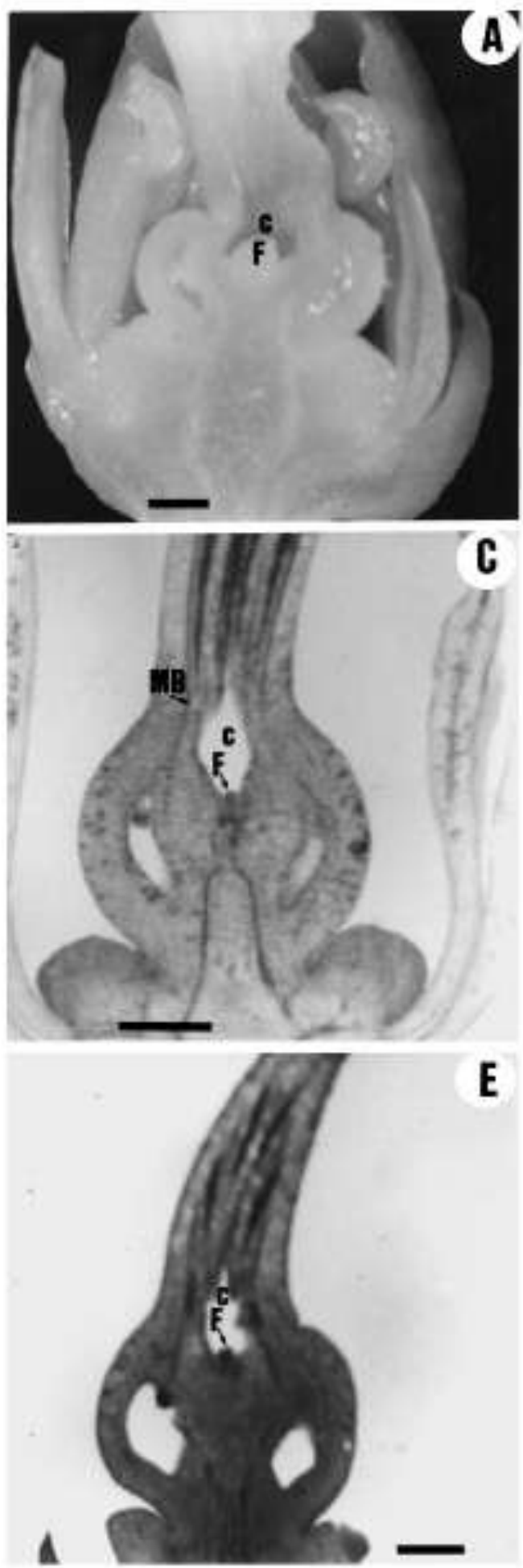
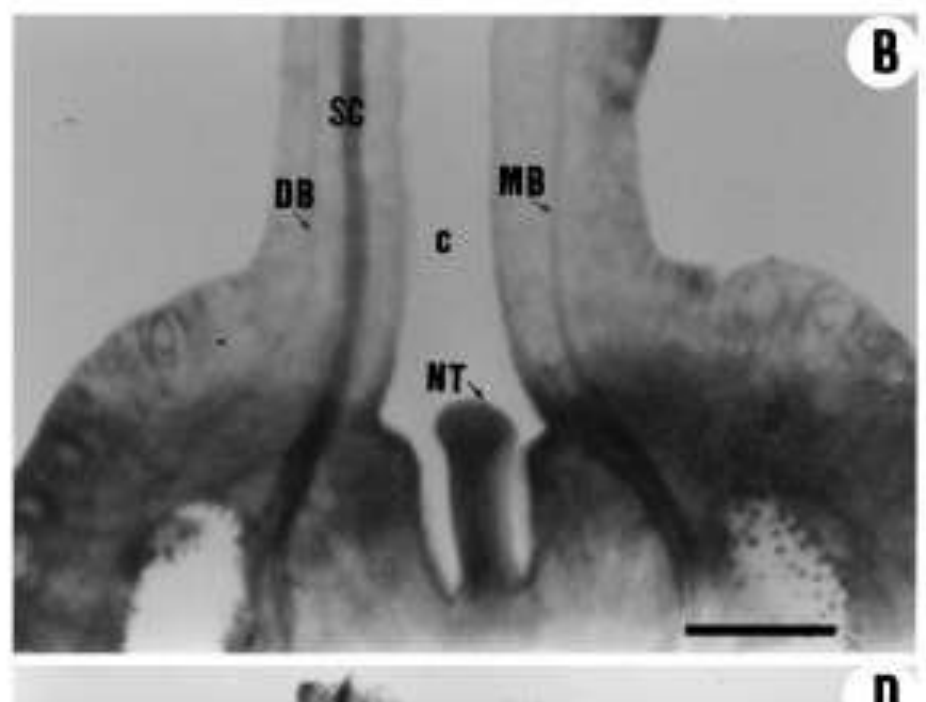

D
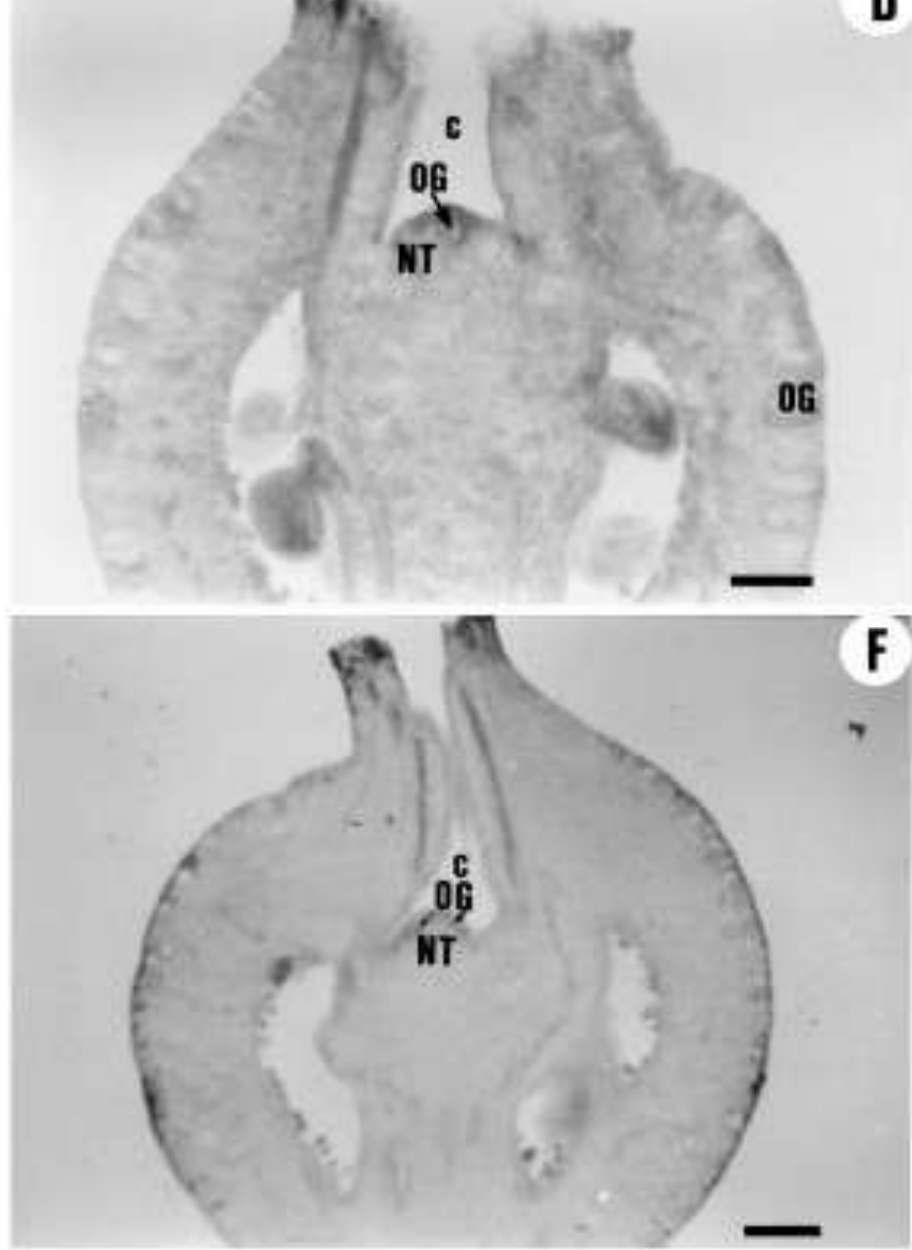

Fig. 7. Longitudinal sections of the pistils and developing fruitlets of hybrid mandarins showing the conserved - oral meristem, the cavity at the stylar end of the ovaries and fruitlets, and the initial stages of navel growth at the time of style abscission, with the formation of a rind-like tissue with oil glands. (A) Flower bud of Murcott. (B) Developing fruitlet of Murcott shortly before style abscission. (C) Flower bud of Ellendale shortly before anthesis. (D) Fruitlet of Ellendale shortly after the abscission of the style. (E) Ovary of Nova at anthesis. (F) Fruitlet of Nova at style abscission. Scale bars: $1 \mathrm{~mm}$. C: cavity; DB: dorsal vascular bundle; F: ' marginal vascular bundle; NT: navel tissue; SC: stylar canal; OG: oil gland. 


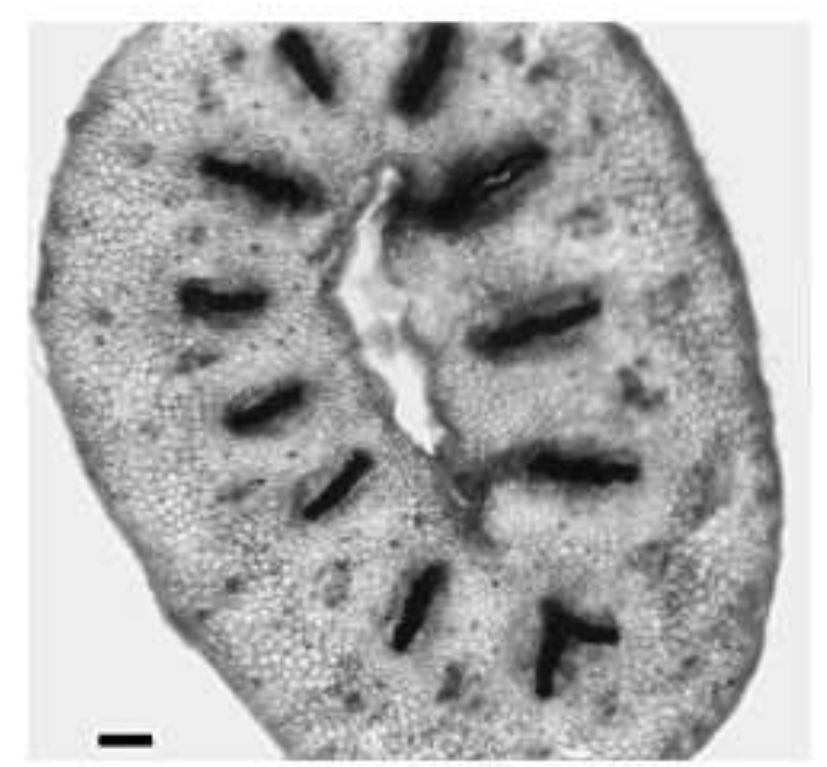

Fig. 8. Transverse section of the style of Nova hybrid. There is an empty central cavity lined by an epidermis. Scale bar: $1 \mathrm{~mm}$.

\subsection{The anatomy of the fruit in relation to splitting in Nova hybrid mandarin}

\subsubsection{The effect of hormone applications on fruit characteristics}

Both $\mathrm{GA} 3$ and 2,4-D increased the early growth rate of the fruitlets, and by mid-June the diameter of the fruitlets was bigger in the treated trees than in the untreated controls (Table 2). The effect of $\mathrm{GA}_{3}$ on fruitlet growth was transient, and at maturity the GA3-treated fruits were slightly but signi®cantly ( $P$ 0.05) smaller in diameter than the untreated fruit (Fig. 10). The effect of 2,4-D on fruitlet growth was more marked than for $\mathrm{GA}_{3}$ (Table 2) and lasted until the end of fruit development, resulting in a bigger fruit size at maturity (P 0.01, Fig. 10).

There were differences in the in ${ }^{-}$uence of the hormone applications on fruit shape and anatomy. By mid-June, the GA3-treated fruit was more oblate (had a higher diameter to height ratio $(\mathrm{D} / \mathrm{H})$ ) than fruit treated with 2,4-D (Table 2). This difference in fruit shape was transient, and from early August onwards fruit shape was similar in both hormone treatments and less oblate than in the controls. In all treatments the fruit became more oblate during development. The change in the $\mathrm{D} / \mathrm{H}$ ratio was maximal during September \pm October, coinciding with the fastest increase in fruit diameter.

The application of 2,4-D increased peel thickness and the size of the navel tissue (Table 2), whilst the application of $\mathrm{GA} 3$ did not affect these parameters. The effect of 2,4-D on peel thickness was most marked at the stylar end of the fruit. In 2,4-D-treated fruits the peel was of a similar thickness at the stylar end than at the median cross-section (Table 2). In the controls and the GA3-treated fruit, the peel was markedly thinner at the stylar end. 

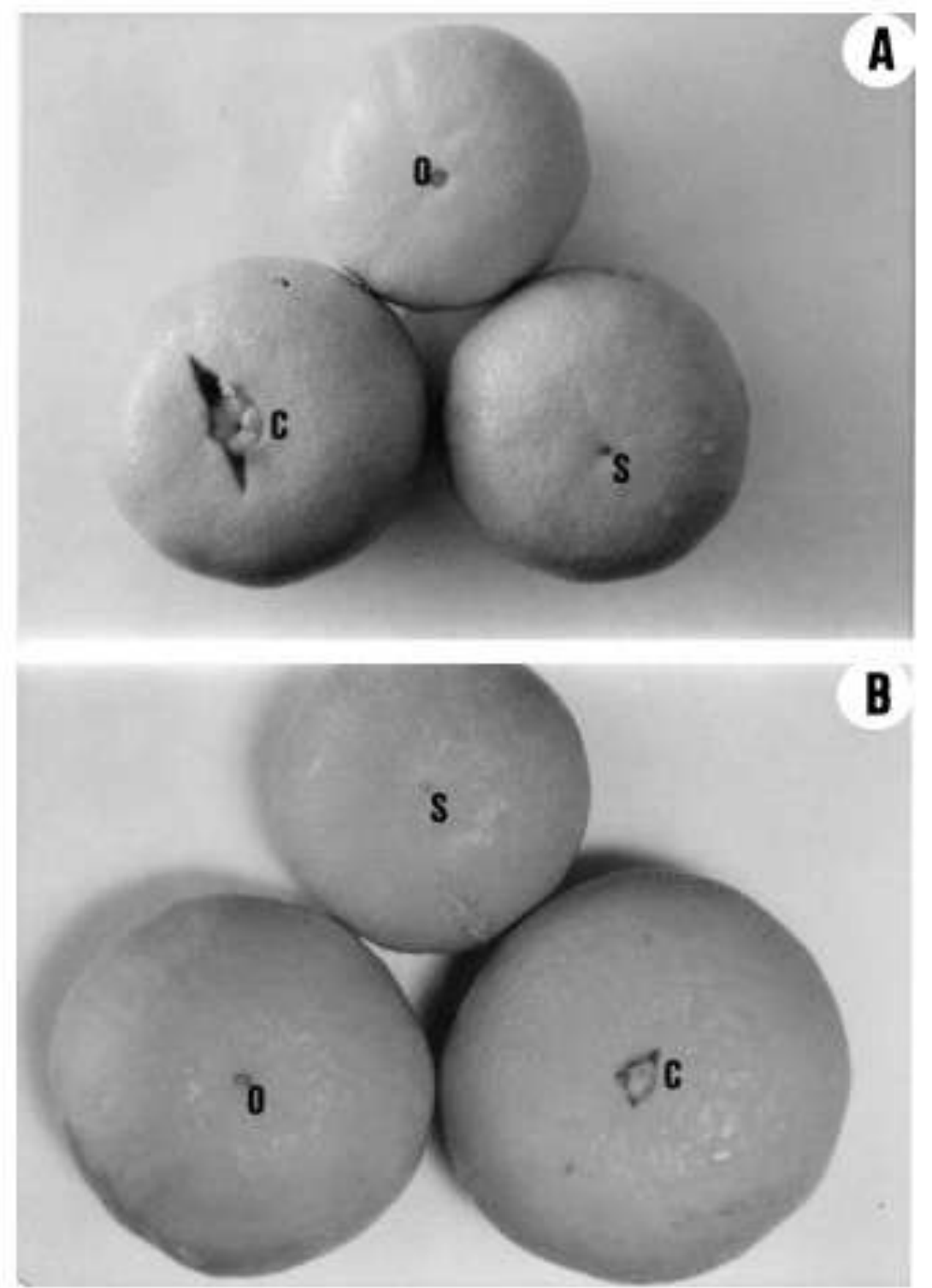

Fig. 9. Morphology of the stylar end of the fruit at harvest: (A) Nova; (B) Murcott. C: fruits with small star cracks at the open stylar end; O: fruits with an open stylar end and an internal navel; S: fruits with a small ( $1 \pm 2 \mathrm{~mm}$ wide) style scar.

\subsubsection{Morphological and anatomical characteristics of the split fruit}

In all treatments, fruit splitting was associated with a more oblate fruit shape and a bigger size of the navel (Table 3). In the control and the GA3-treated fruits, the split fruit had a thinner peel at the stylar end than the non-split fruit. The 2,4D-treated fruits, on the contrary, had a higher peel thickness at the stylar end than the non-split control fruits. Splitting was unrelated to fruit diameter and to peel thickness in the median cross-section of the fruit (Table 3).

The more oblate shape of the split fruit was already signißcant in all treatments by 13 August, some 1 month before splitting started (Table 4). These early measurements conßrmed that splitting was unrelated to fruit diameter, but the fruit prone to split had a smaller height than non-splitting fruit. The ANOVA 
Table 2

The effect of $\mathrm{GA} 3$ and 2,4-D sprays on fruitlet characteristics in Nova hybrid mandarina

\begin{tabular}{|c|c|c|c|c|c|c|c|}
\hline \multirow[t]{2}{*}{ Treatment } & \multicolumn{3}{|c|}{ Fruitlet size $(\mathrm{mm})$ and shape } & \multicolumn{2}{|c|}{ Peel thickness (mm) } & \multicolumn{2}{|c|}{ Navel size (mm) } \\
\hline & Diameter & Height & $\begin{array}{l}\mathrm{D} / \mathrm{H} \\
\text { ratio }\end{array}$ & $\begin{array}{l}\text { In median } \\
\text { cross-section }\end{array}$ & $\begin{array}{l}\text { At the } \\
\text { stylar end }\end{array}$ & Width & Length \\
\hline Untreated & 20.0a & $16.6 a$ & $1.22 a b$ & $4.5 a$ & $4.0 \mathrm{a}$ & 2.1 & $2.1 \mathrm{a}$ \\
\hline 2,4-D-treated & $23.5 c$ & $19.7 b$ & $1.20 \mathrm{a}$ & $4.9 b$ & $4.8 b$ & 2.6 & $3.2 b$ \\
\hline GA3-treated & $21.2 b$ & $16.8 \mathrm{a}$ & $1.27 b$ & $4.3 a$ & $3.8 a$ & 2.5 & $2.3 a$ \\
\hline S.E. & 0.14 & 0.30 & 0.02 & 0.1 & 0.13 & 0.2 & 0.26 \\
\hline Significance & $* *$ & $* *$ & * & ** & ** & NS & ** \\
\hline
\end{tabular}

a Values are mean of the three samples of 10 fruits each, picked on 5, 12 and 19 July. Signißcance of the differences among treatments determined by an ANOVA. Means separation $\left(P^{\wedge} 0.05\right)$ within a column by Tukey \pm Kramer multiple comparison test.

*,**Signi®cant at $\mathrm{P} 0.05$ and $\mathrm{P} 0.01$, respectively.

showed that for the mean of all treatments, this difference in fruit height was close to statistical signi®cance (P 0.06). The distribution of the fruits according to their $\mathrm{D} / \mathrm{H}$ ratio was markedly different for the populations of splitting and nonsplitting fruits (Fig. 11). The frequency of splitting increased with the D/H ratio, and those fruits having a $\mathrm{D} / \mathrm{H}$ ratio at that time smaller than $1.15 \mathrm{did}$ not split later in development.

Table 3

Morphological and anatomical characteristics of split and non-split fruits of Nova hybrid mandarin sampled on 29 Septembera

\begin{tabular}{|c|c|c|c|c|c|c|c|}
\hline \multirow{2}{*}{$\begin{array}{l}\text { Characteristics } \\
\text { and treatment }\end{array}$} & \multicolumn{3}{|c|}{ Fruit size (mm) and shape } & \multicolumn{2}{|c|}{ Peel thickness (mm) } & \multicolumn{2}{|c|}{ Navel size (mm) } \\
\hline & Diameter & Height & $\begin{array}{l}\mathrm{D} / \mathrm{H} \\
\text { ratio }\end{array}$ & $\begin{array}{l}\text { In median } \\
\text { cross-section }\end{array}$ & $\begin{array}{l}\text { At the } \\
\text { stylar end }\end{array}$ & Width & Length \\
\hline \multicolumn{8}{|l|}{ Split fruit } \\
\hline Untreated & $50.7 a$ & $38.3 a$ & $1.33 b$ & 2.56 & $1.77 \mathrm{a}$ & $5.6 a$ & $5.7 \mathrm{~b}$ \\
\hline 2,4-D-treated & $53.4 a b$ & $40.0 \mathrm{~b}$ & $1.34 \mathrm{~b}$ & 2.64 & $2.25 \mathrm{c}$ & $9.4 b$ & $9.5 c$ \\
\hline GA3-treated & $50.9 a$ & $38.9 a b$ & $1.31 b$ & 2.55 & $1.79 \mathrm{a}$ & $6.1 \mathrm{a}$ & $5.6 b$ \\
\hline Non-split & $51.4 a$ & $41.2 b$ & $1.25 a$ & 2.61 & $2.02 b$ & $5.2 \mathrm{a}$ & $3.4 a$ \\
\hline S.E. & 0.8 & 0.8 & 0.015 & 0.07 & 0.07 & 0.5 & 0.7 \\
\hline Significance & ** & ** & ** & NS & $* \star$ & ** & ** \\
\hline
\end{tabular}

Values are mean from 50 fruits. Mean separation $\left(\mathrm{P}^{\wedge} 0.05\right)$ within a column by Tukey \pm Kramer multiple comparison test.

**Signi®cant at $\mathrm{P} 0.05$ and $\mathrm{P} 0.01$, respectively. 

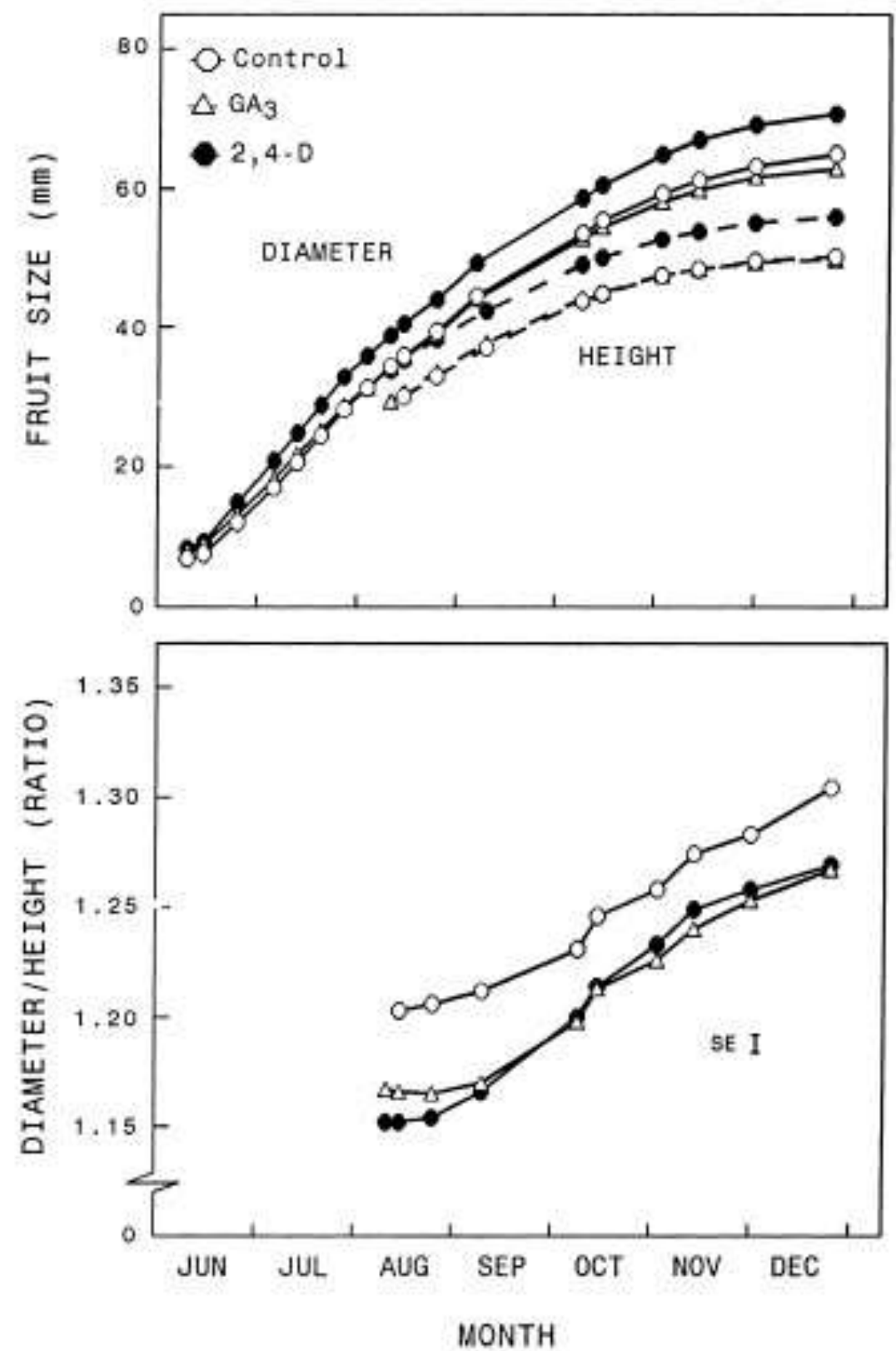

Fig. 10. Time-course of the increase in height and diameter, and changes in the diameter to height ratio, in Nova fruits from untreated control trees, and trees sprayed with 2,4-D or GA3. Values are means of $73 \pm 101$ fruits evenly distributed on 40 trees. The standard error for the diameter and height measurements range from 0.9 to $1.1 \mathrm{~mm}$, about one third of the size of the symbols in the line drawings.

\subsubsection{The effect of hormone treatments on fruit set and splitting}

The application of 2,4-D reduced the number of fruits set, while the application of $\mathrm{GA}_{3}$ increased it. This increase in fruits set was close to statistical signi®cance (P 0.06).

The application of $\mathrm{GA}_{3}$ increased the number of split fruits in the same proportion to fruit set, so that the percentage of splitting was not affected. The application of 2,4-D reduced splitting both in absolute (number of split fruits per tree) and in relative (percentage of set fruits which split) terms (Table 5). 
Table 4

Fruit size and shape of split and non-split fruits of Nova hybrid mandarin measured on 13 August, 1 month before the beginning of splittinga

\begin{tabular}{|c|c|c|c|}
\hline $\begin{array}{l}\text { Fruit characteristics } \\
\text { and treatments }\end{array}$ & Diameter (mm) & Height (mm) & $\mathrm{D} / \mathrm{H}$ ratio \\
\hline \multicolumn{4}{|l|}{ Untreated fruit } \\
\hline Non-split (n^74) & 35.8 Æ 1.3 & 30.0 Æ 1.2 & 1.20 Æ 0.012 \\
\hline Split (n^28) & 35.0 Æ 2.2 & 27.4 Æ 1.9 & 1.28 Æ 0.026 \\
\hline \multicolumn{4}{|l|}{ GA3-treated fruit } \\
\hline Non-split (n^73) & 35.6 Æ 1.0 & 30.6 Æ 0.9 & 1.17 Æ 0.012 \\
\hline Split $\left(n^{\wedge} 14\right)$ & 35.9 Æ 1.7 & 27.8 Æ 1.7 & 1.30 Æ 0.047 \\
\hline \multicolumn{4}{|l|}{ 2,4-D-treated fruit } \\
\hline Non-split (n^101) & 40.4 Æ 1.0 & 35.2 Æ 1.0 & 1.15 Æ 0.015 \\
\hline Split $\left(\mathrm{n}^{\wedge} 10\right)$ & 42.9 Æ 2.3 & 33.6 Æ 1.7 & 1.28 Æ 0.045 \\
\hline
\end{tabular}

\footnotetext{
a Values are meanÆES.E.
}

\section{Discussion}

Fruit splitting results from the physical pressures of the rapidly expanding juice vesicles on the peel layers. These pressures stretch the albedo layer (mesocarp), whose cells enlarge tangentially during the period of rapid pulp growth while

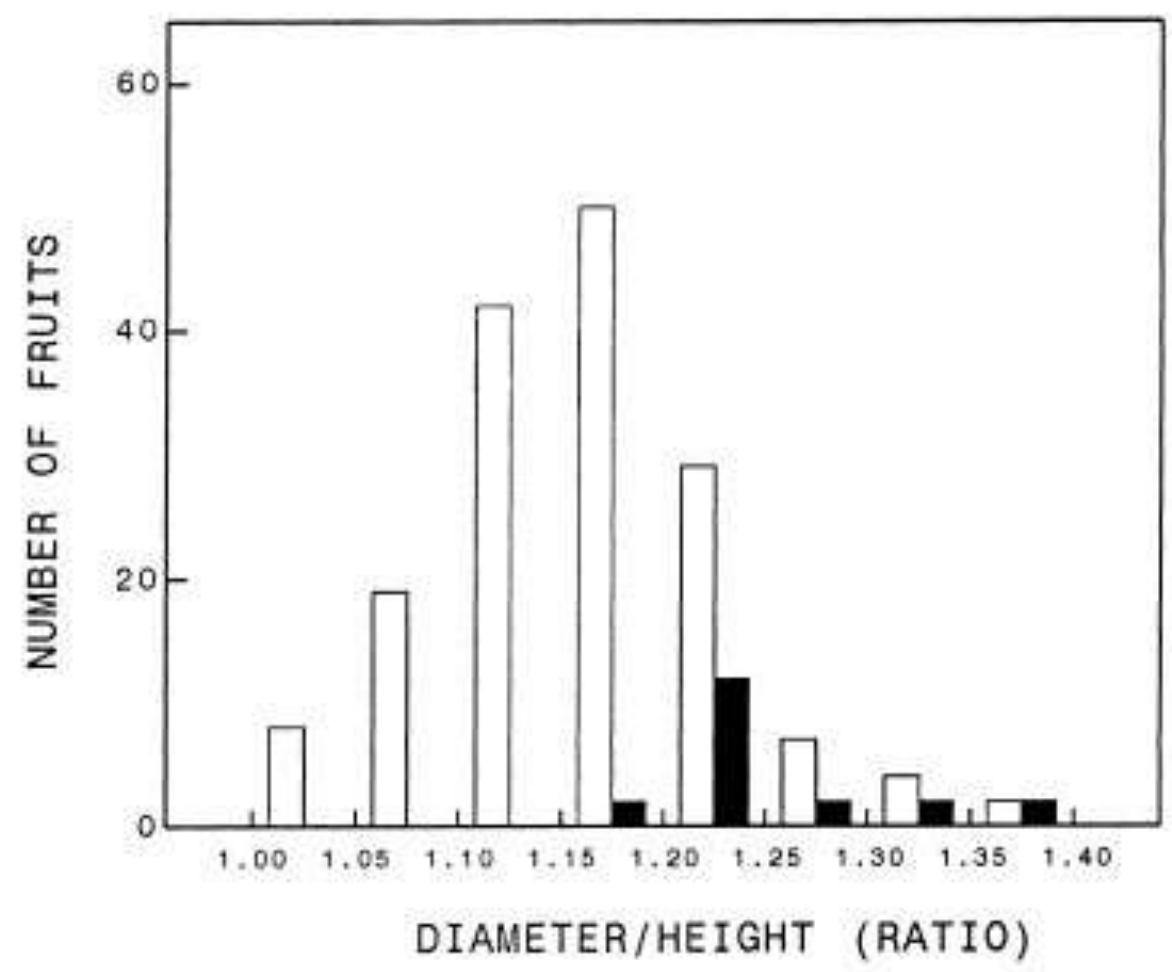

Fig. 11. Distribution of a random population of 180 fruits of Nova according to their diameter to height ratio on 9 August, 1 month before splitting started. Open bars: fruits which did not split; dark bars: fruits which split at later stages of development. 
Table 5

The effect of hormone treatments on fruit set and splitting in Nova hybrid mandarina

\begin{tabular}{llll}
\hline $\begin{array}{l}\text { Hormone } \\
\text { treatment }\end{array}$ & $\begin{array}{l}\text { Fruit set } \\
\text { (units per tree) }\end{array}$ & $\begin{array}{l}\text { Split fruit } \\
\text { (units per tree) }\end{array}$ & $\begin{array}{l}\text { Percentage } \\
\text { of splitting }\end{array}$ \\
\hline $\begin{array}{lll}\text { Untreated } \\
2,4-\text { - }\end{array}$ & $503 \mathrm{a}$ & $87 \mathrm{~b}$ & $18 \mathrm{a}$ \\
GA3-treated & $345 \mathrm{~b}$ & $41 \mathrm{a}$ & $12 \mathrm{~b}$ \\
& $601 \mathrm{a}$ & $113 \mathrm{c}$ & $19 \mathrm{a}$ \\
S.E. & 37 & 5.6 & 2 \\
Significance & $*$ & $* *$ & \\
\hline
\end{tabular}

a Mean separation ( $\left.\mathrm{P}^{\wedge} 0.05\right)$ by Tukey \pm Kramer multiple comparison test.

${ }^{*},{ }^{* *}$ Signißcant at $\mathrm{P} 0.05$ and $\mathrm{P} 0.01$, respectively.

decreases (Bain, 1958; Guardiola and Lazaro, 1987), and

Âtheir radial diameter

may lead eventually to peel collapse and cracking. The intensity of the stresses

generated by the pressures, together with peel resistance and plasticity,

determines the intensity of cracking and the location of the cracks. These

parameters must be considered in the comparative behaviour of the cultivars.

An oblate form of the fruit increases the stresses at the poles (calyx and stylar ends), and this effect of shape on stress increases markedly when the $\mathrm{D} / \mathrm{H}$ ratio of the fruit becomes higher than about 1.25 (Considine and Brown, 1981). The three hybrids studied are oblate-spheroid in shape (Hodgson, 1967), the $\mathrm{D} / \mathrm{H}$ ratio of Nova in our plant material reaching a mean value of 1.30 at maturity (Fig. 10). The concentration of the stresses at the stylar (and the calyx) end in the fruit of these hybrids is therefore much higher than in the slightly oblate to globose clementines, whose $\mathrm{D} / \mathrm{H}$ ratio is much lower ( 1.115 for Fino clementine;

Gonzalez-Sicilia, 1968), and this factor may determine, at least in part, the differences in splitting among these two groups of cultivars. A favourable fruit shape, however, does not seem the factor that prevents cracking in satsuma, as its fruit is oblate to subglobose with a mean $\mathrm{D} / \mathrm{H}$ ratio of 1.258 (Gonzalez-Sicilia, 1968), similar to the value reported for Murcott (1.28; Goldschmidt et al., 1992).

The relevance of fruit shape in the determination of splitting is supported by the time-course of this alteration and the comparison of split and non-split fruits in Nova. As described for other cultivars (Susanto and Nakajima, 1990; Goldschmidt et al., 1992; Richardson et al., 1997), the fruit of Nova becomes more oblate during the main period of growth (Fig. 10). The mean peak of splitting in our experiments occurred during September, when the mean $\mathrm{D} / \mathrm{H}$ ratio of the fruit rose from 1.21 to 1.23 (Fig. 10). In addition, the split fruit was more oblate than the non-split fruit (Table 4), and this difference in fruit shape was signi®cant at least 1 month before the beginning of splitting (Table 4, Fig. 11). Further, although the hormone treatments markedly affected fruit shape, the split fruit had a similar $\mathrm{D} / \mathrm{H}$ ratio in all treatments and this ratio was higher than for the 
non-split fruit (Table 4). In line with these results it is noteworthy that De Cicco et al. (1988) found that splitting in Navelina orange decreased as the $H / D$ ratio (the inverse to the $\mathrm{D} / \mathrm{H}$ ratio) increased. Saunt (1990) states that cracking fruit in Ellendale is ${ }^{-}$attened in shape.

In all cultivars, the ovaries were formed by the postgenital union of initially separated carpels (Fig. 1), but the process of fusion varied markedly among cultivars and led to structural differences at the stylar end of the fruit. In most of the fruits of clementine and satsuma, the abaxial side of the inwardly curved carpels fused with the - ower axis beyond the stylar end of the ovary (Figs. 3 and 6). The contacting epidermal cells redifferentiated into parenchyma cells indistinguishable from the cells of the ground tissue (Figs. 3A, B and 6). This resulted in a compact and homogeneous albedo layer at the stylar end of the fruit (Fig. 5), which in most cases only presented a small scar at the place of style abscission (Table 1). In the hybrids, the - oral axis did not reach the apex of the fruit, which resulted in the formation of an empty cavity instead of a solid tissue (Fig. 7). The rind-like tissue formed by the - ower meristem enlarges this cavity, resulting in the formation of a structurally weak stylar end in most of the fruits, in which small cracks are usually found even in fruits reaching maturity (Fig. 9, Table 1). By mechanical considerations, it has been shown that the presence of a hole at the pole of an oblate fruit greatly increases the stresses and the incidence of star cracking (Considine and Brown, 1981). A bigger stylar end aperture in the split as compared to the non-split fruit has been reported in Washington navel orange (Lima and Davies, 1984) and in Nova (García-Luis et al., 1994).

On theoretical grounds, it may be expected that an increase in peel thickness should increase the mechanical resistance of the peel and reduce splitting. Some reports have shown an inverse relationship between peel thickness and splitting when fruits from different orchards are compared (De Cicco et al., 1988; Almela et al., 1994). In our experiments, in which trees from the same Nova plot were compared, splitting was unrelated to peel thickness at the median cross-section of the fruit (Table 3). On the other hand, the split fruit had a thinner peel at the stylar end than non-split fruit, but whether this difference determines the incidence of splitting or merely re ${ }^{-}$ects the cessation of growth which occurs at the stylar end of the fruit prior to splitting (García-Luis et al., 1994) remains to be demonstrated. In any case, stylar peel thickness may not be the only determinant factor of splitting, since it is bigger in split 2,4-D-treated fruit than in non-split control fruit (Table 3).

The purpose of our hormone applications was to correlate their effect on splitting with the changes in the anatomy and the structure of the fruit. Both $\mathrm{GA}_{3}$ and 2,4-D affected fruit shape similarly, resulting in a more oblate fruit, yet they had different effects on splitting. Contrary to what could be expected from its effect on fruit shape, $\mathrm{GA}_{3}$ failed to decrease splitting, which was increased to the same extent as fruit set (Table 5). This effect of $\mathrm{GA}_{3}$ con®rms previous reports 
showing an increase in splitting, both in absolute and relative terms, by $\mathrm{GA}_{3}$ applications at ${ }^{-}$owering in Nova (Goren et al., 1992; Almela et al., 1994; GarcíaLuis et al., 1994) and Ellendale (Rabe and Van Rensburg, 1996). In addition to the effect on fruit shape, 2,4-D markedly increased the growth of the navel, a factor which increases splitting (Table 3; Lima and Davies, 1984; García-Luis et al., 1994). Yet splitting was reduced by the 2,4-D application. The increase of peel thickness at the stylar end may contribute to this effect (Table 3). In addition to it, this application markedly affected rind structure, affecting both cell size and the thickness of the ${ }^{-}$avedo (evidence not presented).

The objective of this work was to attempt to relate the propensity of the citrus cultivars to split to the anatomical features of the ovaries/fruitlets. All the proneto-split cultivars studied had an oblate fruit, an open stylar end and a welldeveloped navel tissue, while the less sensitive cultivars lacked several or all these features. The relevance of these parameters in relation to splitting is supported by the differences between split and non-split fruits within the Nova cultivar. However, the response to the application of growth regulators demonstrated that other factors, in addition to the ones studied in this work, are relevant to splitting.

\section{Acknowledgements}

This research was funded by grants from Fundación Séneca de la Consejería de Medio Ambiente, Agricultura y Agua, Región de Murcia, Spain (Grant 00502/ CV/98) and from Ministerio de Educación and Cultura, Spain (Grant PB950736). Thanks are due to Mr. Joaquin Llusar for providing orchard facilities, and to Ing. Francisco Llatser, Avasa, Benicarló, for the plant material used in this study. Scholarships from Ministerio de Educación y Ciencia, Spain, to MK, and from the Programa CIENCIA-Junta Nacional de Investigacão Científica y Tecnológica (JNICT) of Portugal to AMMD, are gratefully acknowledged.

\section{References}

Alexander, D.McE., 1983. Some citrus species and varieties in Australia. CSIRO, Adelaide.

Almela, V., Zaragoza, S., Primo-Millo, E., Agustõ, M., 1994. Hormonal control of splitting in Nova mandarin fruit. J. Hort. Sci. 69, 969-973.

Bain, J.M., 1958. Morphological, anatomical and physiological changes in the developing fruit of the Valencia orange, Citrus sinensis (L.) Osbeck. Aust. J. Bot. 6, 1-28.

Bar-Akiva, A., 1975. Effect of potassium nutrition on fruit splitting in 'Valencia' orange. J. Hort. Sci. $50,85 \pm 89$.

Barry, G.H., Bower, J.P., 1997. Manipulation of fruit set and stylar-end fruit split in Nova mandarin hybrid. Sci. Hort. 70, 243-250. 
Considine, J., Brown, K., 1981. Theoretical analysis of distribution of surface growth forces in fruit in relation to cracking and splitting. Plant Physiol. $68,371 \pm 376$.

De Cicco, V., Intrigliolo, F., Ippolito, A., Vanadia, S., Guifridda, A., 1988. Factors in Navelina orange splitting. Proc. Int. Soc. Citricult. 1, 535 \pm 540 .

del Rivero, J.M., 1968. Los Estados de Carencia en los Agrios. Mundi Prensa, Madrid.

Erickson, L.C., 1968. The general physiology of citrus. In: Reuther, W., Batchelor, L.D., Webber, H.J. (Eds.), The Citrus Industry, Vol. II. University of California, Berkeley, CA, pp. 86 \pm 126 .

García-Luis, A., Duarte, A.M.M., Porras, I., García-Lidon, A., Guardiola, J.L., 1994. Fruit splitting in 'Nova' hybrid mandarin in relation to the anatomy of the fruit and fruit set treatments. Sci. Hort. 57, 215 \pm 231 .

Goldschmidt, E.E., Galili, D., Rabber, D., 1992. Fruit splitting in 'Murcott' tangerines. Control by reduced water supply. Proc. Int. Soc. Citricult. 1, 657 \pm 660 .

ÂGonzalez-Sicilia, E., 1968. El Cultivo de los Agrios, 3rd Edition. Editorial Bello, Valencia.

Goren, R., Huberman, M., Riov, J., 1992. Effects of gibberellin and girdling on the yield of 'Nova'

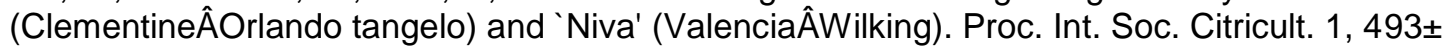
499.

Guardiola, J.L., Lazaro, E., 1987. The effect of synthetic auxins on fruit growth and anatomical development in 'Satsuma' mandarin. Sci. Hort. 31, 119 \pm 130.

Hodgson, R.W., 1967. Horticultural varieties of citrus. In: Reuther, W., Webber, H.J., Batchelor, L.D. (Eds.), The Citrus Industry, Vol. I. University of California, Berkeley, CA, pp. 431 \pm 588.

Jensen, W.A., 1962. Botanical Histochemistry. Freeman, San Francisco, CA.

Johansen, A., 1940. Plant Microtechnique. McGraw-Hill, New York, p. 96.

Lima, J.E.O., Davies, F.S., 1984. Fruit morphology and drop of navel oranges in Florida. HortScience 19, 262 \pm 263 .

Monselise, S.P., Costo, J., Galili, D., 1986. Additional experiments to reduce the incidence of citrus fruit splitting by 2,4-D and calcium. Alon Hanotea 40, 1237 \pm 1238 .

Rabe, E., Van Rensburg, P.J.J., 1996. Gibberellic acid sprays, girdling, ' ower thinning and potassium applications affect fruit splitting and yield in the Ellendale tangor. J. Hort. Sci. 71, $195 \pm 203$.

Richardson, A.C., Marsh, K.B., Macrae, E.A., 1997. Temperature effects on satsuma mandarin fruit

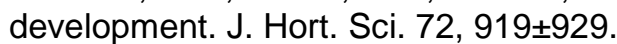

Ruiz, LI., Primo-Millo, E., 1989. El rajado, agrietado o "splitting" de los frutos cõtricos. Levante Agric. 291, 98 \pm 102 .

Saunt, J., 1990. Citrus Varieties of the World. Sinclair International Ltd.

Susanto, S., Nakajima, Y., 1990. Effect of winter heating on ${ }^{-}$owering time, fruiting and fruit development in pummelo grown in a winter house. J. Jpn. Soc. Hort. Sci. 56, 375 \pm 391 . 